\title{
LETTER
}

\section{Patient-centered outcomes and trials of hydroxyethyl starch}

John Myburgh ${ }^{1,2^{*}}$, Simon Finfer ${ }^{1,3}$ and Rinaldo Bellomo ${ }^{1,4}$

Meybohm and colleagues [1] propose that hydroxyethyl starch (HES) may be used safely in hypovolemic patients by applying a clinical algorithm and by restricting the dose administered.

The authors question the validity of the results of the two trials that constitute over $60 \%$ of current data $[2,3]$ and misleadingly state that in the Crystalloid vs. Hydroxyethyl Starch Trial (CHEST), HES administration did not increase the use of renal replacement therapy by referring to the adjusted analyses that were published in the electronic supplement [2]. The unadjusted analysis was pre-specified as the principal outcome measure and is the appropriate measure to influence clinical practice. The authors also ignore the consistent signal of harm associated with HES, specifically increased mortality and use of renal replacement therapy that is evident despite wide variations in aggregate doses of HES in the three major clinical trials: $70 \mathrm{ml} / \mathrm{kg}$ in the Efficacy of Volume Substitution and Insulin Therapy in Severe Sepsis trial [4], $44 \mathrm{ml} / \mathrm{kg}$ in the Scandinavian Starch for Severe Sepsis/Septic Shock study [3], and $5 \mathrm{ml} / \mathrm{kg}$ in CHEST. Meybohm and colleagues make no comment that adverse effects of HES represent an overall toxic effect caused by increased tissue accumulation that is recognised as a dose-dependent, generic HES effect [5].

The 'presumably correct indication' and the algorithm they propose have not been validated nor are they supported by any credible clinical evidence. Their proposed algorithm and target population must be evaluated in rigorously conducted randomized controlled trials before being considered for adoption into clinical practice. Given the consistent evidence that HES is nephrotoxic and may increase mortality [6], it is doubtful that institutional ethics committees would approve such a trial, or that informed patients would consent to participate.

\footnotetext{
* Correspondence: jmyburgh@georgeinstitute.org.au

${ }^{1}$ The George Institute for Global Health, Level 13, 321 Kent Street, Sydney 2000, Australia

${ }^{2}$ St George Clinical School, University of New South Wales, Gray Street, Kogarah, Sydney 2217, Australia
}

Abbreviations

CHEST: Crystalloid vs. Hydroxyethyl Starch Trial; HES: Hydroxyethyl starch.

\section{Competing interests}

JM reports receiving travel support and grant support to his institution (the George Institute through the University of Sydney) from Fresenius Kabi, and travel support and advisory fees to his institution (the George Institute) from Baxter. SF reports receiving travel support and grant support to his institution (the George Institute through the University of Sydney) from Fresenius Kabi, and travel support and advisory fees to his institution (the George Institute) from Baxter. RB reports no disclosures in relation to this manuscript.

\section{Author details}

${ }^{1}$ The George Institute for Global Health, Level 13, 321 Kent Street, Sydney 2000, Australia. ${ }^{2}$ St George Clinical School, University of New South Wales, Gray Street, Kogarah, Sydney 2217, Australia. ${ }^{3}$ Royal North Shore Hospital, University of Sydney, Reserve Road, St Leonards, Sydney 2065, Australia. ${ }^{4}$ Austin Hospital, University of Melbourne, Studley Road, Heidelberg, Melbourne 3084, Australia.

Published: 27 Sep 2013

\section{References}

1. Meybohm P, Van Aken H, De Gasperi A, De Hert S, Della Rocca G, Girbes AR, Gombotz H, Guidet B, Hasibeder W, Hollmann MW, Ince C, Jacob M, Kranke P, Kozek-Langenecker S, Loer SA, Martin CD, Siegemund M, Wunder C, Zacharowski K: Re-evaluating currently available data and suggestions for planning randomised controlled studies regarding the use of hydroxyethyl-starch in critically ill patients - a multidisciplinary statement. Crit Care 2013, 17:R166.

2. Myburgh JA, Finfer S, Bellomo R, Billot L, Cass A, Gattas D, Glass P, Lipman J, Liu B, McArthur C, McgGuinness S, Rajbhandari D, Taylor CB, Webb SAR, the CHEST Investigators and the Australian and New Zealand Intensive Care Society Clinical Trials Group: Hydroxyethyl starch or saline for fluid resuscitation in intensive care. N Engl J Med 2012, 367:1901-1911.

3. Perner A, Haase N, Guttormsen AB, Tenhunen J, Klemenzson G, Aneman A, Madsen KR, Møller MH, Elkjær JM, Poulson LM, Bendtsen A, Winding R, Steensen M, Berezowicz P, Søe-Jensen P, Bestle M, Strand K, Wiis J, White JO, Thornberg KJ, Quiset L, Nielsen J, Andersen LH, Holst LB, Thormar K, Kjældgaard A-L, Fabritius ML, Mondrup F, Pott FC, et al: Hydroxyethyl starch 130/0.42 versus Ringer's acetate in severe sepsis. N Engl J Med 2012, 367:124-134.

4. Brunkhorst FM, Engel C, Bloos F, Meier-Hellmann A, Ragaller M, Weiler N, Moerer O, Gruendling M, Oppert M, Grond S, Olthoff D, Jaschinski U, John S, Rossaint R, Welte T, Schaefer M, Kern P, Kuhnt E, Kiehntopf M, Hartog C, Natanson C, Loeffler M, Reinhart K, German Competence Network Sepsis (SepNet): Intensive insulin therapy and pentastarch resuscitation in severe sepsis. N Engl J Med 2008, 358:125-139. 
5. Bellmann R, Feistritzer C, Wiedermann CJ: Effect of molecular weight and substitution on tissue uptake of hydroxyethyl starch: a meta-analysis of clinical studies. Clin Pharmacokinet 2012, 51:225-236.

6. Mutter TC, Ruth CA, Dart AB: Hydroxyethyl starch (HES) versus other fluid therapies: effects on kidney function. Cochrane Database Syst Rev 2013, 7, CD007594.

$10.1186 / \mathrm{cc} 13023$

Cite this article as: Myburgh et al:: Patient-centered outcomes and trials of hydroxyethyl starch. Critical Care 2013, 17:452 